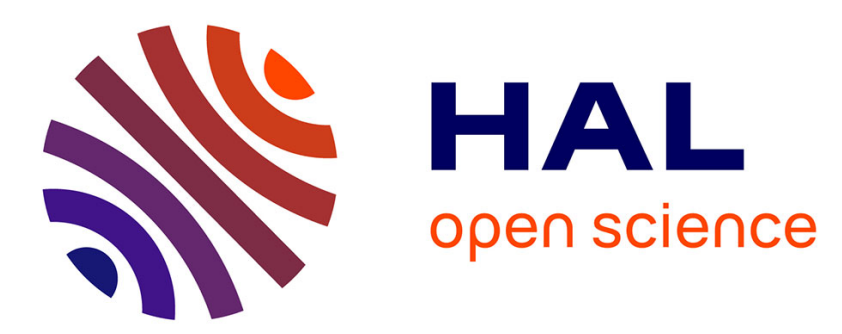

\title{
Higher efficiency of triethanolamine-grafted anion exchange membranes for acidic wastewater treatment
}

Muhammad Khan, Jinzhan Su, Eric Lichtfouse, Liejin Guo

\section{To cite this version:}

Muhammad Khan, Jinzhan Su, Eric Lichtfouse, Liejin Guo. Higher efficiency of triethanolaminegrafted anion exchange membranes for acidic wastewater treatment. Desalination and Water Treatment, 2020, 194, pp.41-51. 10.5004/dwt.2020.25966 . hal-02928591

\section{HAL Id: hal-02928591 \\ https://hal.science/hal-02928591}

Submitted on 2 Sep 2020

HAL is a multi-disciplinary open access archive for the deposit and dissemination of scientific research documents, whether they are published or not. The documents may come from teaching and research institutions in France or abroad, or from public or private research centers.
L'archive ouverte pluridisciplinaire HAL, est destinée au dépôt et à la diffusion de documents scientifiques de niveau recherche, publiés ou non, émanant des établissements d'enseignement et de recherche français ou étrangers, des laboratoires publics ou privés. 


\title{
Higher efficiency of triethanolamine-grafted anion exchange membranes for acidic wastewater treatment
}

\author{
Muhammad Imran Khan*, Jinzhan Su, Eric Lichtfouse, Liejin Guo* \\ International Research Centre for Renewable Energy (IRCRE), State Key Laboratory of Multiphase Flow in Power Engineering (MPFE), \\ Xi'an Jiaotong University, 28 West Xianning Road, Xi'an 710049, China, emails: raoimranishaq@gmail.com (M.I. Khan), \\ j.su@xjtu.edu.cn (J.Z.Su), eric.lichtfouse@inra.fr (E. Lichtfouse), lj-guo@mail.xjtu.edu.cn (L.J. Guo)
}

\begin{abstract}
A B S T R A C T
Acidic wastewaters are major industrial effluents that must be cleaned before release in natural waters, yet classical treatment methods are limited. Diffusion dialysis through anion exchange membranes (AEM) appears as a sustainable alternative because those membranes are cheap and highly selective, yet there is a need for improved membranes. Here we synthesized AEMs from brominated poly(2,6-dimethyl-1,4-phenylene oxide) using triethanolamine as an ion-exchange group for acid recovery. The prepared membranes were characterized by Fourier-transform infrared spectroscopy, scanning electron microscopy, and atomic force microscopy. Acid recovery was tested with a mixture of $\mathrm{HCl}$ and $\mathrm{FeCl}_{2}$. Results show that increasing triethanolamine content into the membrane polymer matrix led to an increase of water uptake from $12 \%$ to $117 \%$, ion exchange capacity from 1.28 to $2.29 \mathrm{mmol} / \mathrm{g}$, and linear swelling ratio from $3.52 \%$ to $32.70 \%$. The diffusion dialysis coefficient of acid $\left(\mathrm{U}_{\mathrm{H}}^{+}\right)$reached $23 \times 10^{-3} \mathrm{~m} / \mathrm{h}$, which is higher than that actual membranes, of $0.37-20 \times 10^{-3} \mathrm{~m} / \mathrm{h}$. $\mathrm{U}_{\mathrm{H}}^{+}$increased with membrane triethanolamine content, which is explained by increasing $\mathrm{H}$ bonding of aqueous protons with membrane hydroxyl groups. $\mathrm{U}_{\mathrm{H}}^{+}$also increased from $23 \times 10^{-3} \mathrm{~m} / \mathrm{h}$ at $25^{\circ} \mathrm{C}$ to $71 \times 10^{-3} \mathrm{~m} / \mathrm{h}$ at $55^{\circ} \mathrm{C}$ due to easier ion flow. Moreover, the separation factor (S) reached 495 at $25^{\circ} \mathrm{C}$, which is higher than that of actual membranes, of 73-351. The diffusion dialysis coefficient of metal $\left(\mathrm{U}_{\mathrm{Fe}}^{2+}\right)$ ranged from 0.0025 to $6110^{-3} \mathrm{~m} / \mathrm{h}$. Membranes also showed excellent thermal, chemical and mechanical stability.
\end{abstract}

Keywords: Triethanolamine; Brominated poly(2,6-dimethyl-1,4-phenylene oxide) (BPPO); Anion exchange membrane; Water uptake; Acid recovery

\section{Introduction}

Acidic wastewaters are produced in large amounts from industrial processes such as electroplating, metallurgy, and mining. Acidic wastewaters induce two major issues, environmental pollution when effluents are discharged in rivers, and corrosion, which is costly [1,2]. Common processes for wastewater treatment include neutralization, crystallization, thermal decomposition, solvent extraction, precipitation, coagulation-flocculation, distillation, and electrodialysis $[3,4]$, yet these processes have drawbacks such as cost, low selectivity, high energy and the use of toxic chemicals. Alternatively, diffusion dialysis through ion exchange membranes is actually under active research investigation because it is operationally cheaper, it consumes less energy and is potentially more efficient [5-16]. In particular, anion exchange membranes (AEM) are wellsuited for acid separation and recycling [17-23], yet the performances of actual membranes are limited.

The diffusion dialysis process is driven by a gradient of compound concentration between the two sides of the ion exchange membrane. Ion exchange membranes can

\footnotetext{
* Corresponding authors.
} 
be classified into AEM and cation exchange membranes according to the ionic group attached to the polymeric backbone. Currently, AEMs are tested for acid recovery from industrial acidic wastewater. Membranes have been synthesized from polysulfone and polystyrene, by photo-initiated polymerization of 4-vinylpyridine with varying amounts of divinylbenzene in the pores of polypropylene, by surface modification and pore filling of various polymers [24-27]. Nonetheless, those membranes usually lack stability, and their hydrophobicity limits ion transfer during diffusion dialysis. Therefore, there is a need for cost-effective membranes that have long-term stability, higher selectivity, and permeation for acid recovery and wastewater treatment.

AEMs can be improved by modifying the polymeric backbone and functional groups $[6,12,13,19,28]$. Indeed, the polymeric backbone should be hydrophobic and mechanically stable. Actual polymeric backbones include poly(arylene ether ketone) [29,30], poly(arylene ether sulfone) [31-33], poly(fluorenyl ether ketone sulfone) [34], poly(vinyl alcohol) [35], poly(2,6-dimethyl-1,4-phenylene oxide) [36,37], and polyetherimide [38]. Besides, the ion exchange capacity (IEC) should be high because well connected ion-conducting channels improve the diffusion dialysis coefficient [39]. The anion permeability can be controlled by the functional groups such as guanidinium [40-43], sulfonium [44] and phosphonium [45-49].

Membranes including quaternary ammonium are cheap and easy to synthesize [10]. Here, a higher proton diffusion coefficient $\mathrm{U}_{\mathrm{H}}^{+}$of $0.033 \mathrm{~m} / \mathrm{h}$ and a high separation factor $\mathrm{S}$ of 95.45 at $25^{\circ} \mathrm{C}$ has been obtained with quaternary ammonium-functionalized poly(arylene ether) (QPAE-Br) membranes [28]. A diffusion dialysis coefficient $U_{H}^{+}$of $0.019 \mathrm{~m} / \mathrm{h}$ and a separation factor $S$ of 127 was reported for series-connected hexacations cross-linked membranes [6]. Quaternized poly(2,6-dimethyl-1,4-phenylene oxide) (PPO) membranes displayed IEC value of $2.07 \mathrm{mmol} / \mathrm{g}$, diffusion coefficient $\mathrm{U}_{\mathrm{H}}^{+}$ of $0.020 \mathrm{~m} / \mathrm{h}$ and a separation factor $\mathrm{S}$ of 73 at room temperature [50]. Highly charged hierarchical porous membranes increased the performance of diffusion dialysis with higher diffusion dialysis coefficient $\mathrm{U}_{\mathrm{H}}^{+}$of $0.0273 \mathrm{~m} / \mathrm{h}$ and a separation factor $\mathrm{S}$ of 86.5 at $25^{\circ} \mathrm{C}$ [51]. Poly(DMAEM-co-g-MPS) gave a diffusion dialysis coefficient $\mathrm{U}_{\mathrm{H}}^{+}$of $0.016-0.029 \mathrm{~m} / \mathrm{h}$ and a separation factor $\mathrm{S}$ of 23.3-87.7 [8]. PPO has good mechanical properties and allows easy membrane preparation for high acid recovery at room temperature $[7,9,10]$.

Triethanolamine (TEA) appears as a better reagent for membrane preparation, compared to other quaternary ammonium groups. Indeed triethanolamine bears three highly hydrophilic hydroxyl groups $(-\mathrm{OH})$, which act as assisting groups to improve $\mathrm{H}^{+}$transfer during dialysis $[12,13]$. Secondly, the low acidity of triethanolamine, with pKa of 10.75, allows higher anion permeability because anions are dissociated easier from functional groups [16]. In addition, the high alkalinity of triethanolamine induces higher adsorption of water molecules on positive groups, which, in turn, facilitates the conduction of anions [16].

Here we present the first attempt to employ triethanolamine as a functional group in AEMs. Membrane properties were tailored by varying the triethanolamine content of the polymeric matrix. Membranes were characterized by Fourier-transform infrared spectroscopy (FTIR), and for morphology, IEC, water uptake, linear swelling ratio (LSR), thermal, chemical, and mechanical stability. Membranes were tested for acid recovery with a mixture of $\mathrm{HCl}$ and $\mathrm{FeCl}_{2}$ by diffusion dialysis. The effect of temperature on the dialysis performance was also tested.

\section{Experimental setup}

\subsection{Materials}

PPO from Sigma-Aldrich (Germany). Triethanolamine, chlorobenzene, ethanol, chloroform, $\mathrm{N}$-methyl-2-pyrrolidone (NMP), 2,2'-azobisisobutyronitrile (AIBN), N-bromosuccinimide (NBS), sodium chloride $(\mathrm{NaCl})$, silver nitrate $\left(\mathrm{AgNO}_{3}\right)$, sodium sulfate $\left(\mathrm{Na}_{2} \mathrm{SO}_{4}\right)$, potassium chromate $\left(\mathrm{K}_{2} \mathrm{CrO}_{4}\right)$, hydrochloric acid $(\mathrm{HCl})$, ferrous chloride $\left(\mathrm{FeCl}_{2} \cdot 4 \mathrm{H}_{2} \mathrm{O}\right)$, methyl orange (MO) from Sinopharm Chemical reagent $\mathrm{Co}$. Ltd, China. Distilled water was used.

\subsection{Preparation of brominated $P P O$}

Synthesis has been described [52] (Fig. 1). Typically, $6 \mathrm{~g}$ of PPO $(50 \mathrm{mmol})$ is dissolved into $50 \mathrm{ml}$ chlorobenzene in a round bottom flask containing a magnetic stirrer and reflexed condenser. $4.45 \mathrm{~g}$ NBS ( $25 \mathrm{mmol})$ and $0.25 \mathrm{~g}$ azobisisobutyronitrile (AIBN, $1.5 \mathrm{mmol}$ ) are added and the solution is stirred at $135^{\circ} \mathrm{C}$ for $3 \mathrm{~h}$. After cooling to $25^{\circ} \mathrm{C}$, the reaction mixture is poured into an excess of ethanol to precipitate the polymer. The polymer is filtered, washed with ethanol, re-dissolved into $60 \mathrm{~mL}$ chloroform then precipitated into an excess of ethanol. The polymer is collected as a light-yellow powder and dried under vacuum for $2 \mathrm{~d}$ at $40^{\circ} \mathrm{C}$ to yield brominated poly(2,6-dimethyl-1,4-phenylene oxide) (BPPO) with a bromination ratio of $75 \%$.

\subsection{Fabrication of AEMs}

We used the solution casting method to prepare membranes [7,53-57]. We prepared a $8 \% \mathrm{w}$ solution by dissolving $0.8 \mathrm{~g}$ of BPPO into $10 \mathrm{~mL}$ of NMP. $0.15,0.25,0.35$, or $0.45 \mathrm{~g}$ of triethanolamine were added to obtain membranes named TEA-19, TEA-31, TEA-44, and TEA-56 respectively, where $19,31,44$, and 56 refer to the weight percentage (w\%) of triethanolamine into the membrane matrix. The reaction mixture was stirred $12 \mathrm{~h}$ at $40^{\circ} \mathrm{C}$ then casted onto a glass plate at $60^{\circ} \mathrm{C}$ for $24 \mathrm{~h}$. Membranes were peeled off from glass plates and cleaned with deionized water. The chemical structure of the prepared membrane is also shown in Fig. 1.

\subsection{Characterization}

\subsubsection{Instrumentation}

${ }^{1} \mathrm{H}-\mathrm{NMR}$ (proton nuclear magnetic resonance) with DMX 300 NMR spectrometer operating at $300 \mathrm{MHZ}$ was used to monitor the bromination of PPO. AEM was analysed for attenuated total reflectance with a Vector 22, Bruker, (Massachusetts, MA, USA) FTIR spectrometer at 4,000 $400 \mathrm{~cm}^{-1}$. Field-emission scanning electron microscopy (FE-SEM, Sirion 200, FEI Company, USA) and atomic force microscopy (AFM) were used to observe the membrane morphology. Membrane thermal stability was tested using a Shimadzu Corporation, (Kyoto, Japan) TGA-50H analyzer under nitrogen flow with a heating rate of $10^{\circ} \mathrm{C} / \mathrm{min}$ from 

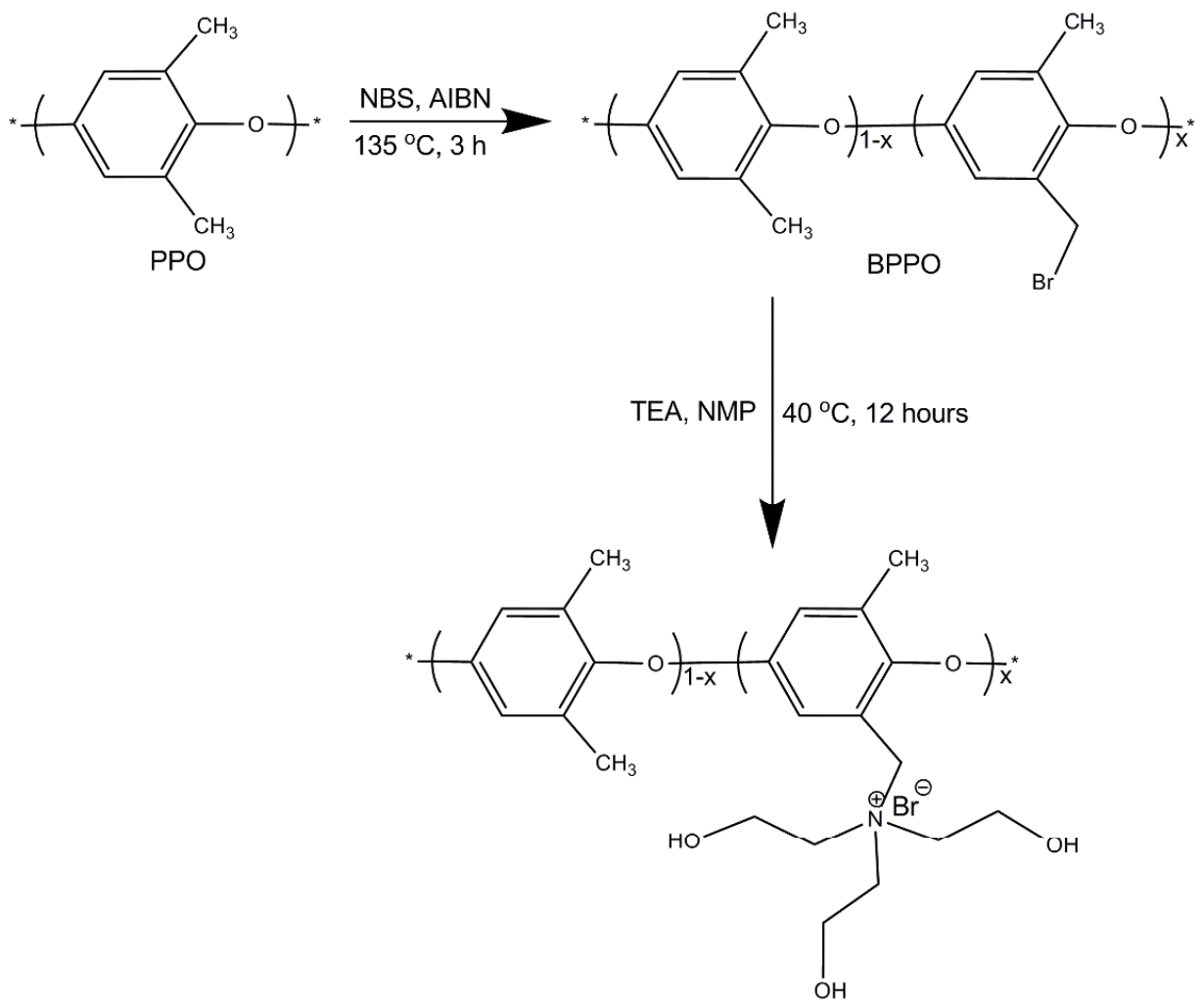

AEM

Fig. 1. Preparation of brominated poly(2,6-dimethyl-1,4-phenylene oxide) (BPPO)-based anion exchanged membranes. NBS: N-Bromo-succinimide; AIBN: 2,2'-azobisisobutyronitrile; TEA: triethanolamine, NMP: N-methyl-2-pyrrolidone, AEM: anion exchange membrane.

$25^{\circ} \mathrm{C}$ to $800^{\circ} \mathrm{C}$. Membrane mechanical stability was measured using Q800 dynamic mechanical analyzer (DMA, TA Instruments, Kyoto, Japan) at a stretch rate of $0.5 \mathrm{~N} / \mathrm{min}$

\subsubsection{Ion exchange capacity}

IEC of membranes was determined by Mohr's method. Typically, the dried membrane samples were immersed in $1 \mathrm{M} \mathrm{NaCl}$ for $48 \mathrm{~h}$ to convert the charged sites into the $\mathrm{Cl}^{-}$ form. Excess $\mathrm{NaCl}$ was removed from membranes by careful water cleaning then immersion into $0.5 \mathrm{M} \mathrm{Na}_{2} \mathrm{SO}_{4}$ for $48 \mathrm{~h}$. The concentration of released $\mathrm{Cl}^{-}$was determined by titration with $0.05 \mathrm{M} \mathrm{AgNO}_{3}$ using $\mathrm{K}_{2} \mathrm{CrO}_{4}$ as an indicator, and was calculated using the following equation [53]:

$\mathrm{IEC}=\frac{C_{\mathrm{AgNO}_{3}} V_{\mathrm{AgNO}_{3}}}{W_{\text {Dry }}}$

where $m, V$, and $C$ depict the dry weight of the membrane sample, titer value during titration, and the concentration of $\mathrm{AgNO}_{3}$ solution, respectively.

\subsubsection{Water uptake and $L S R$}

To measure water uptake of the prepared membranes, the dried membrane samples were weighed and then immersed in water for $24 \mathrm{~h}$ at room temperature. After removing the surface water with tissue paper, wet weight was measured. Water uptake was calculated from the mass difference before and after the complete drying of the membranes, using the following equation $[57,58]$ :

$W_{\mathrm{R}}=\frac{W_{\mathrm{WET}}-W_{\mathrm{DRY}}}{W_{\mathrm{DRY}}} \times 100 \%$

where $W_{\text {WET }}$ and $W_{\text {DRY }}$ depict the wet and dry weights of membrane samples, respectively.

The LSR was measured at $25^{\circ} \mathrm{C}$. The membranes sample was cut into a $3 \mathrm{~cm}^{2} \times 3 \mathrm{~cm}^{2}$ pieces. The ratio was obtained using the following equation [54]:

$\mathrm{LER}=\frac{\left(L_{\mathrm{WET}}-L_{\mathrm{DRY}}\right)}{L_{\mathrm{DRY}}} \times 100 \%$

where $L_{\mathrm{WET}}$ and $L_{\mathrm{DRY}}$ denote wet and dry lengths of membrane samples, respectively.

\subsubsection{Chemical stability}

To investigate membrane chemical stability, membrane samples were immersed in $\mathrm{HCl} / \mathrm{FeCl}_{2}$ feed solution at $55^{\circ} \mathrm{C}$. The change in weight as a function of immersion time was calculated to measure chemical stability. 


\subsubsection{Diffusion dialysis of $\mathrm{HCl} / \mathrm{FeCl}{ }_{2}$}

The acid recovery performance of anionic exchange membranes reported in our previous work $[5,9]$. Typically, the experiment was carried out in a two-compartment stack separated by the AEM. The effective area of the used membrane is $5.7 \mathrm{~cm}^{2}$. The membrane sample is conditioned in the feed solution of $0.89 \mathrm{M} \mathrm{HCl}$ and $0.25 \mathrm{M} \mathrm{FeCl}_{2}$ for $5 \mathrm{~h}$, which stimulates waste acid solution prior to the test. One compartment of the stack is filled up with a $100 \mathrm{~mL}$ feed solution, while the other side with $100 \mathrm{~mL}$ deionized water during the experiment. Both solutions are stirred $60 \mathrm{~min}$. vigorously in order to minimize the concentration polarization. Then both feed and permeate are taken from the different compartments. The concentrations of $\mathrm{H}^{+}$in both compartments were measured by titration, while $\mathrm{Fe}^{2+}$ concentration was measured by inductively coupled plasma spectrophotometry (ICP, Optima 7300 DV).

The dialysis coefficient $U$ is calculated using the following equation [10]:

$U=\frac{M}{A t \Delta C}$

where $M$ is the concentration of the transported component in mol, $A$ depicts the effective membrane area in $\mathrm{m}^{2}$, $t$ denotes the time in $h$, and $\Delta C$ represents the logarithm average concentration between the two chambers in $\mathrm{mol} / \mathrm{m}^{3}$. $\Delta C$ is measured as below [10]:

$\Delta C=\frac{C_{f}^{0}-\left(C_{f}^{t}-C_{d}^{t}\right)}{\ln \left[C_{f}^{0} /\left(C_{f}^{t}-C_{d}^{t}\right)\right]}$ where $C_{f}^{0}$ and $C_{f}^{t}$ are feed concentrations at time 0 and $t$, respectively, and $C_{d}^{t}$ is the dialysate.

Dialysis coefficient $\mathrm{U}_{\mathrm{H}}$ and $\mathrm{U}_{\mathrm{Fe}}$ can be measured using Eqs. (4) and (5). The separation factor $S$ is ratio of dialysis coefficients $U$ of the two species present in the solution. $S$ is calculated by [10]:

$\mathrm{S}=\frac{\mathrm{U}_{\mathrm{H}}}{\mathrm{U}_{\mathrm{Fe}}}$

\section{Results and discussion}

\subsection{Bromination of $P P O$}

Brominated poly(2,6-dimethyl-1,4-phenylene oxide) (BPPO) was synthesized by the bromination of PPO by NBS as a brominating agent and AIBN as initiator. Bromination can occur either at the benzylic position or at the aromatic ring depending on the reaction condition and reagents $[52,59]$. In this research, it occurred at the benzylic position of $\mathrm{PPO}$ in refluxing chlorobenzene solution at $135^{\circ} \mathrm{C}$. The structure and degree of BPPO were investigated by ${ }^{1} \mathrm{H}-\mathrm{NMR}$ spectroscopy (Fig. 2). The benzyl bromide group is located at $4.3 \mathrm{ppm}$. The degree of bromination is $75 \%$, it is the percentage of the integral area of the benzyl bromide group vs. the unreacted benzyl signal at $2.1 \mathrm{ppm}$.

\subsection{Quaternization of brominated $P P O$}

FTIR spectroscopy was used to check the quaternization of BPPO with triethanolamine. Fig. 3 shows the FTIR spectra of the pristine BPPO membrane and of the BPPO membrane containing $65 \%$ triethanolamine (TEA-56). The band at $1,608 \mathrm{~cm}^{-1}$ is due to $\mathrm{C}=\mathrm{C}$ stretching in phenyl groups; the

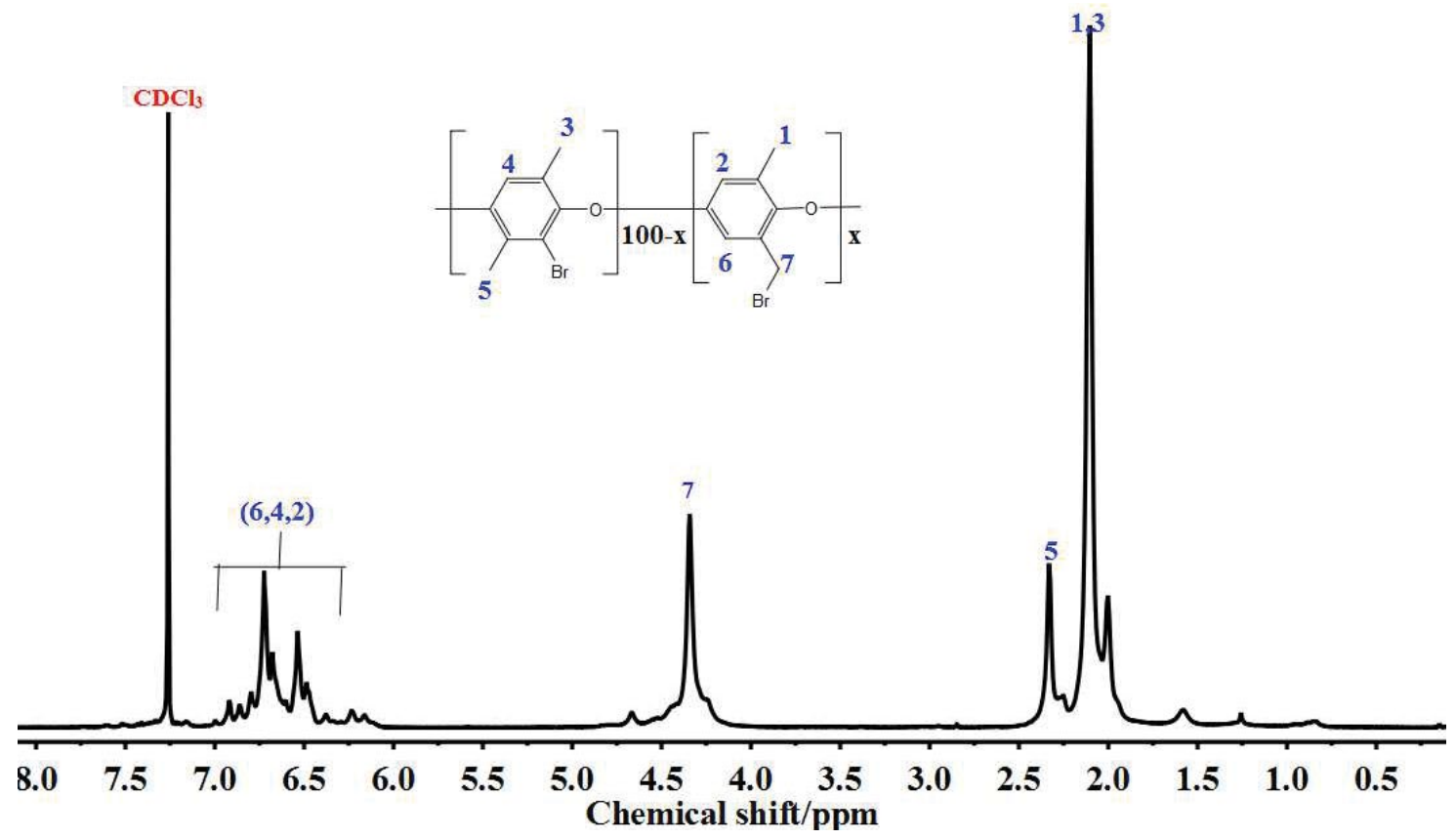

Fig. 2. ${ }^{1} \mathrm{H}-\mathrm{NMR}$ spectrum of brominated poly(2,6-dimethyl-1,4-phenylene oxide) synthesized by bromination of poly(2,6-dimethyl-1,4-phenylene oxide). The presence of a peak at $4.3 \mathrm{ppm}$ reveals the successful bromination at benzylic positions. 


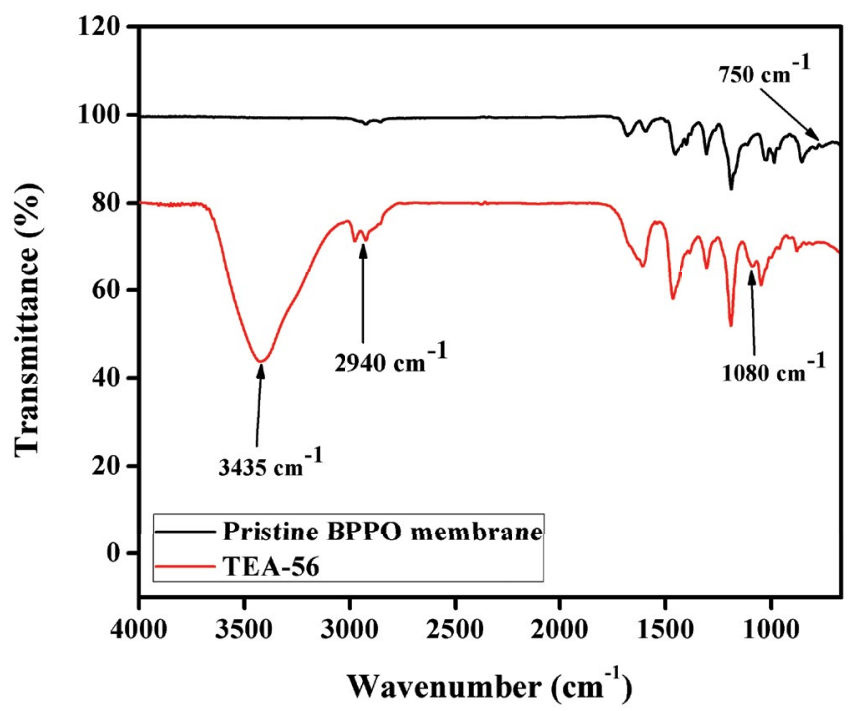

Fig. 3. Infrared spectra of pristine brominated poly(2,6dimethyl-1,4-phenylene oxide) (BPPO) and the membrane prepared with $56 \%$ triethanolamine (TEA-56), confirming successful synthesis.

peak at $1,190 \mathrm{~cm}^{-1}$ is characteristic of $\mathrm{C}-\mathrm{O}-\mathrm{C}$ stretching [60]. The bands at $1,446 \mathrm{~cm}^{-1}$ are attributed to $-\mathrm{CH}$ stretching $(V$ and $\delta$ ) [35]. Symmetrical and asymmetrical stretching of C-O are at 1,200 and 1,306 $\mathrm{cm}^{-1}$, and those of phenyl groups at 1,470 and $1,600 \mathrm{~cm}^{-1}$ respectively [54]. The band at $750 \mathrm{~cm}^{-1}$ is attributed to $\mathrm{C}-\mathrm{Br}$ stretching in the pristine BPPO membrane [61].

The triethanolamine-containing membrane shows a characteristic band at $1,080 \mathrm{~cm}^{-1}$ associated with $\mathrm{C}-\mathrm{N}$ stretching, thus demonstrating the successful reaction of BPPO and triethanolamine. Other characteristic bands include $-\mathrm{OH}$ stretching of triethanolamine at $3,435 \mathrm{~cm}^{-1}$; a peak at $2,940 \mathrm{~cm}^{-1}$ due to the $-\mathrm{CH}_{2}$ group of triethanolamine attached to the BPPO backbone. Noteworthy, the signal for $\mathrm{C}-\mathrm{Br}$ stretching in bromobenzyl groups at $750 \mathrm{~cm}^{-1}$ disappeared after the reaction of triethanolamine with BPPO [61,62]. Overall, our findings confirm the successful grafting of triethanolamine with the BPPO backbone.

\subsection{Membrane morphology}

The morphology of anionic exchange membranes prepared with $19 \%$ and $56 \%$ triethanolamine was studied by scanning electron microscopy (SEM) (Fig. 4a). Results show that membranes are free from any hole or crack in surfaces and cross-sections, thus confirming their homogeneous nature. Moreover, the membrane homogeneity is enhanced by increasing the concentration of triethanolamine into the membrane matrix. This finding is explained by higher miscibility with an increasing amount of triethanolamine into the polymer matrix. Overall, the homogeneous morphology of the membranes makes them suitable for acid recovery via diffusion dialysis. Membrane surfaces were also analyzed by AFM at room temperature (Fig. 4b). Results show again that the membranes are homogeneous without any phase separation.

\subsection{Ion exchange capacity}

The IEC of the prepared membranes, measured by the Mohr's method, is given in Table 1. Results show that the IEC increases from 1.28 to $2.28 \mathrm{mmol} / \mathrm{g}$ by increasing the amount of triethanolamine in the polymer matrix. The IEC depicts the number of exchangeable ion-conducting groups and thus controls the ion conductivity and swelling ratio of membranes. The IEC also provides information on the membrane charge density, which is related to their conductivity and transport properties [54]. Our results thus imply higher anion permeability and, in turn, higher performance for diffusion dialysis.

\subsection{Water uptake and linear swelling ratio}

Table 1 depicts the water uptake of the membranes prepared with $19 \%-56 \%$ triethanolamine at room temperature. Results show an increase in water uptake from $12 \%$ to $117 \%$ with triethanolamine content. This finding implies that hydrophilicity can be controlled and that ion permeability and mechanical properties can be tailored for diffusion dialysis applications. Indeed, water molecules are involved in ion transport and, as a consequence, a moderate water uptake is required for higher anion permeability [16]. Nonetheless, too much water may reduce mechanical and dimensional stability. Overall, our membranes display a suitable water uptake for diffusion dialysis.

Table 1 presents linear swelling ratio (LSR) of prepared membranes. Results show that LSR increases from 3.51\% to $32.70 \%$ with increasing the amount of triethanolamine into the polymer matrix. These findings imply that the membranes exhibit excellent swelling resistance, which is required for diffusion dialysis.

\subsection{Diffusion dialysis coefficient and separation selectivity}

We used a mixture of $\mathrm{HCl}$ and $\mathrm{FeCl}_{2}$ as a model of acidic wastewater to test the membrane performances, similarly to previous reports $[7,9,13]$. The diffusion dialysis coefficient of $\mathrm{HCl}\left(\mathrm{U}_{\mathrm{H}}^{+}\right)$and metal $\left(\mathrm{U}_{\mathrm{Fe}}^{2+}\right)$ of our membranes are shown in Fig. 5a. Results show that $\mathrm{U}_{\mathrm{H}}^{+}$ranges from 1.3 to $23 \times 10^{-3} \mathrm{~m} / \mathrm{h}$, and that $\mathrm{U}_{\mathrm{Fe}}^{2+}$ ranges from 0.0025 to $0.61 \times 10^{-3} \mathrm{~m} / \mathrm{h}$ at room temperature. Our membranes have thus higher $\mathrm{U}_{\mathrm{H}}^{+}$values than the commercial DF-120B membranes $\left(4 \times 10^{-3} \mathrm{~m} / \mathrm{h}\right)$ [7], PVA-based hybrid membranes $\left(11-18 \times 10^{-3} \mathrm{~m} / \mathrm{h}\right)$ [3] and PPO-based membranes $\left(0.37-20 \times 10^{-3} \mathrm{~m} / \mathrm{h}\right)$ at $25^{\circ} \mathrm{C}[50]$.

The increase of $\mathrm{U}_{\mathrm{H}}^{+}$and $\mathrm{U}_{\mathrm{Fe}}^{2+}$ with triethanolamine content is explained by higher water uptake and IEC, leading to enhanced membrane hydrophilicity. In addition, the free hydroxyl groups of triethanolamine are assistant functional groups that accelerate the transport of $\mathrm{H}^{+}$ions through hydrogen bonding [12]. The higher values of $\mathrm{U}_{\mathrm{H}}^{+}$ is explained by the much smaller ionic radius of $\mathrm{H}^{+}$vs. $\mathrm{Fe}^{2+}[63]$

The separation selectivity is calculated by the separation factor $S$, defined as a ratio of $\mathrm{U}_{\mathrm{H}}^{+}$to $\mathrm{U}_{\mathrm{Fe}}^{2+}$. Fig. $5 b$ shows that our membranes have $S$ ranging from 37 to 495 at room temperature. These values are much higher than that of the commercial DF-120B membrane [10], BPAES-based 


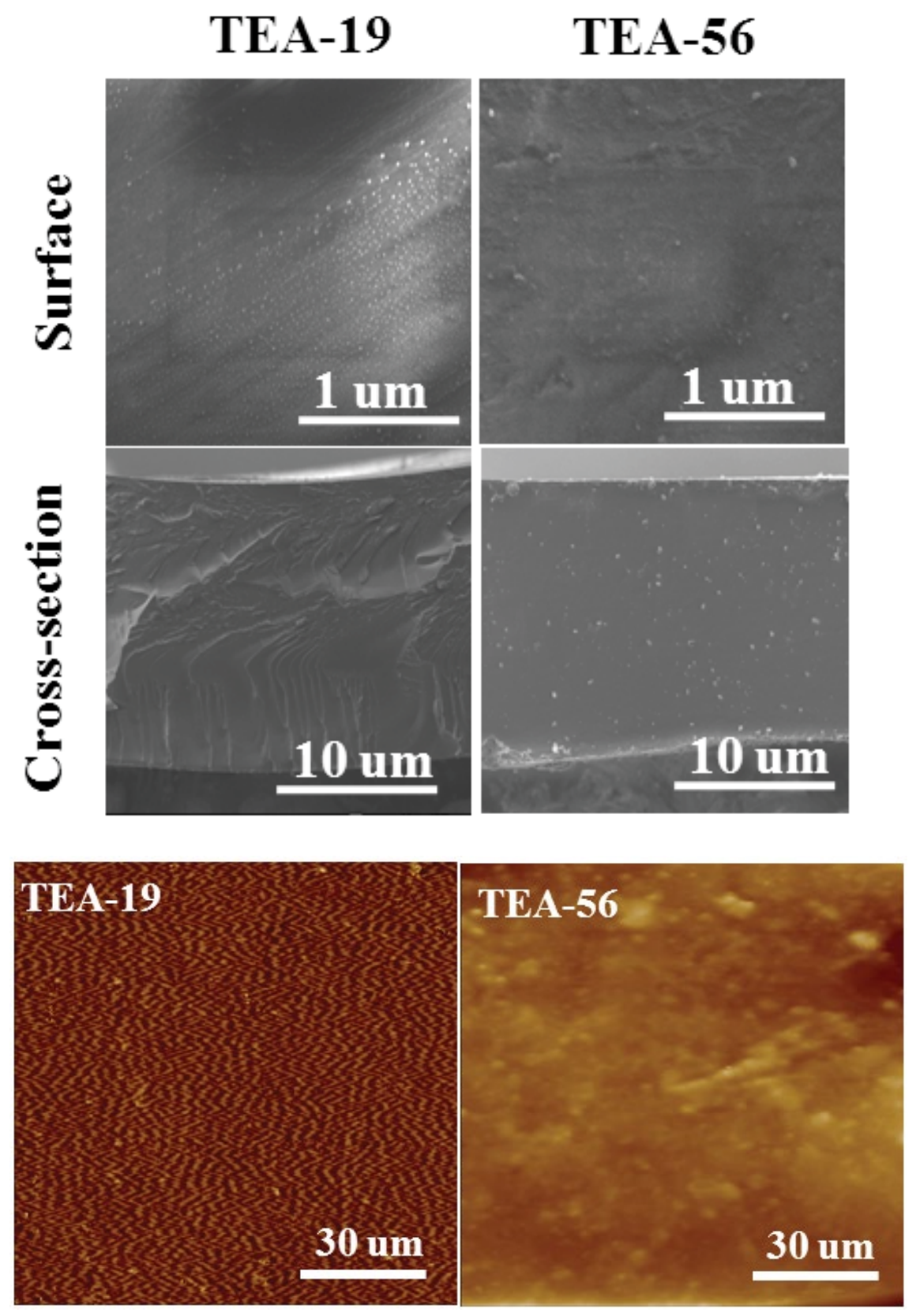

Fig. 4. (a) Surface and cross-section of anionic exchange membranes prepared with 19\% (TEA-19) and 56\% triethanolamine (TEA-56), analyzed by scanning electron microscopy (SEM). (b) Analysis by atomic force microscopy. Results show that membrane surfaces and sections are homogeneous.

Table 1

Theoretical ion exchange capacity (IEC), experimental ion exchange capacity, water uptake $\left(W_{R}\right)$, and linear swelling ratio (LSR) of anionic exchange membranes prepared with $19 \%, 31 \%, 44 \%$, and $56 \%$ of triethanolamine (TEA). Results show that all factors increase with triethanolamine amount in the polymer matrix at $25^{\circ} \mathrm{C}$

\begin{tabular}{lllll}
\hline Membranes & IEC $_{T}(\mathrm{mmol} / \mathrm{g})$ & $\mathrm{IEC}_{\text {Exp. }}(\mathrm{mmol} / \mathrm{g})$ & $W_{R}(\%)$ & LSR $(\%)$ \\
\hline TEA-19 & 1.10 & $1.28 \pm 0.06$ & $12.0 \pm 0.60$ & $3.52 \pm 0.18$ \\
TEA-31 & 1.60 & $1.71 \pm 0.90$ & $37.14 \pm 1.86$ & $10.53 \pm 0.53$ \\
TEA-44 & 2.03 & $1.93 \pm 0.10$ & $49.35 \pm 2.47$ & $15.52 \pm 0.78$ \\
TEA-56 & 2.40 & $2.29 \pm 0.11$ & $117 \pm 5.85$ & $32.70 \pm 1.64$ \\
\hline
\end{tabular}



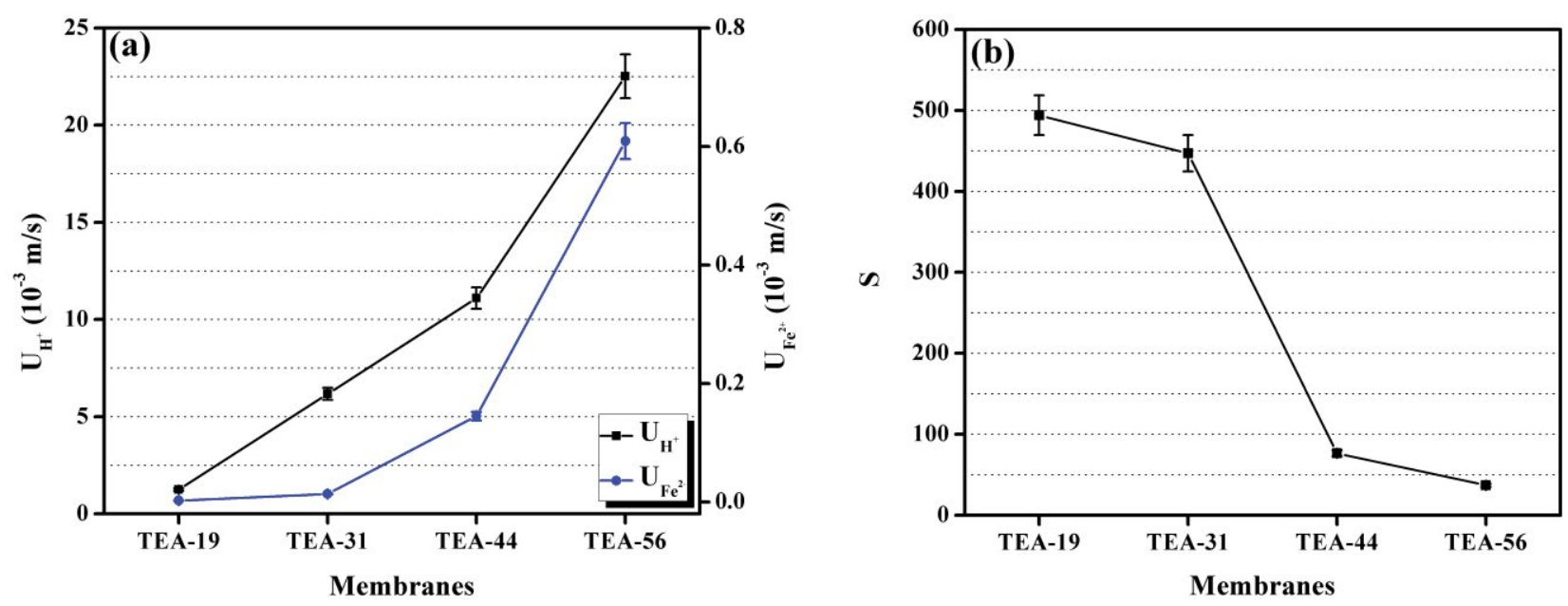

Fig. 5. (a) Diffusion dialysis coefficient of acid, $\mathrm{U}_{\mathrm{H}^{\prime}}^{+}$and metal, $\mathrm{U}_{\mathrm{Fe}^{\prime}}^{2+}$ and (b) separation factor $\mathrm{S}$ for membranes prepared with $19 \%-56 \%$ of triethanolamine (TEA). Results show an increase of $U$ and a decrease of $S$ with triethanolamine content.

membranes [6] and BPPO-Im/GO membranes based membranes [18]. Furthermore, our results show that $\mathrm{S}$ decreases with triethanolamine content (Fig. 5b). This decrease is explained by higher water uptake and swelling ratio (Table 1), which enlarges the spaces between polymer chains and, in turn, favors the permeability of $\mathrm{Fe}^{2+}$.

\subsection{Effect of temperature}

We selected the anionic exchange membrane prepared with $56 \%$ triethanolamine to test the effect of temperature, from $25^{\circ} \mathrm{C}$ to $55^{\circ} \mathrm{C}$, on the performance of diffusion dialysis of $\mathrm{H}^{+}$and $\mathrm{Fe}^{2+}$ (Fig. 6a). Results show an increase of $\mathrm{U}_{\mathrm{H}}^{+}$ from 23 to $71 \times 10^{-3} \mathrm{~m} / \mathrm{h}$, and of $\mathrm{U}_{\mathrm{Fe}}^{2+}$ from 0.61 to $4.2 \times 10^{-3} \mathrm{~m} / \mathrm{h}$ with temperature. These findings agree with enhanced ion transport at higher temperatures $[63,64]$. Further, the effect of temperature on the separation factor $S$ is shown in Fig. 6b. Data shows that $S$ decreases from 37 to 17 with temperature. This finding is explained by the easier transfer of $\mathrm{Fe}^{2+}$ vs. $\mathrm{H}^{+}$at higher temperatures $[63,64]$. Overall the high $\mathrm{U}_{\mathrm{H}}^{+}$values of our membrane imply an excellent diffusion dialysis performance at various temperatures.

\subsection{Comparison of various membranes}

Fig. 7 compares the performances of our membranes with reported membranes $[3,7,17,35,50,63,65-68]$. Two parameters are displayed, the diffusion dialysis coefficient of acid $\mathrm{U}_{\mathrm{H}}^{+}$and the separation factor $\mathrm{S}$. Results show that our membranes have the second-highest $\mathrm{U}_{\mathrm{H}}^{+}$value and the highest separation factor $\mathrm{S}$. Therefore our membranes are very promising for acid recovery from industrial wastewater by diffusion dialysis.

\subsection{Thermal and chemical stability}

We selected the AEM prepared with $56 \%$ triethanolamine to test the thermal stability from $30^{\circ} \mathrm{C}$ to $800^{\circ} \mathrm{C}$ by thermogravimetric analysis. Fig. $8 \mathrm{a}$ shows the thermogravimetric curves of pristine membranes and membranes
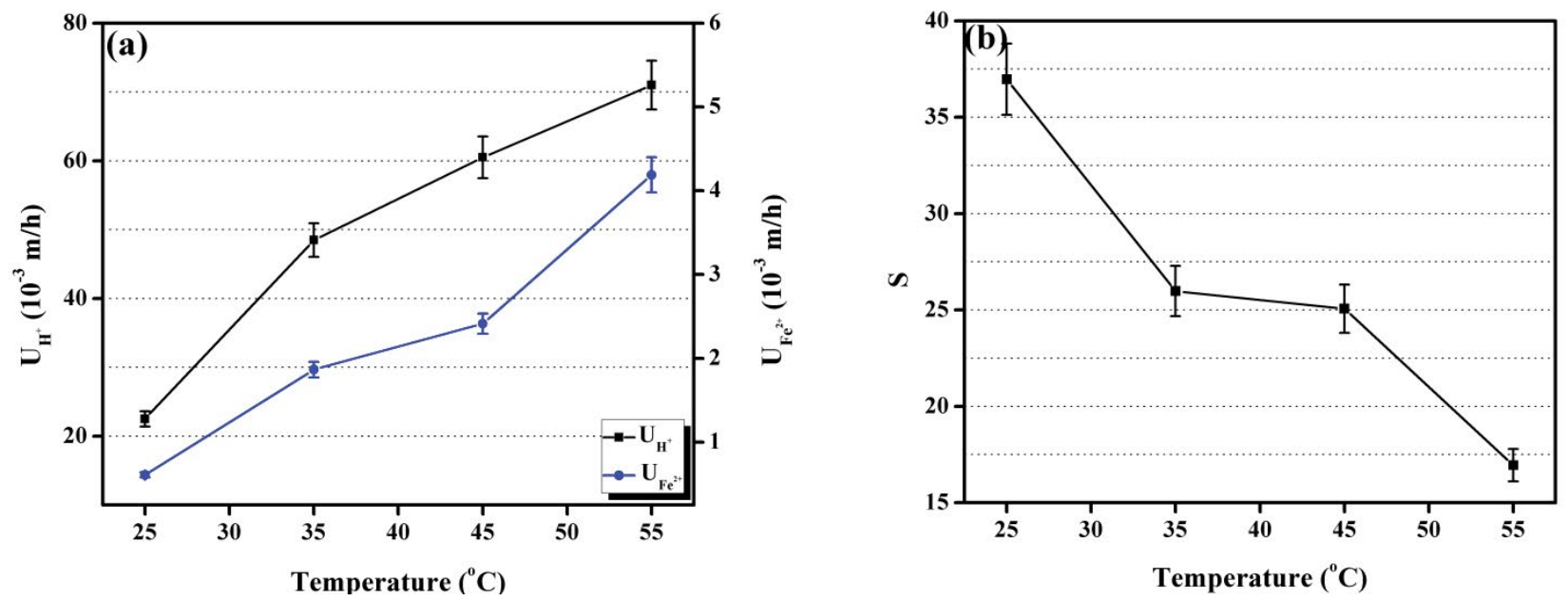

Fig. 6. (a) Diffusion dialysis coefficient of acid $\left(\mathrm{U}_{\mathrm{H}}^{+}\right)$and metal $\left(\mathrm{U}_{\mathrm{Fe}}^{2+}\right)$ and (b) separation factor (S) for the membrane prepared with $56 \%$ triethanolamine (TEA-56). Results show an increase of $U$ and a decrease of $S$ with temperature. 


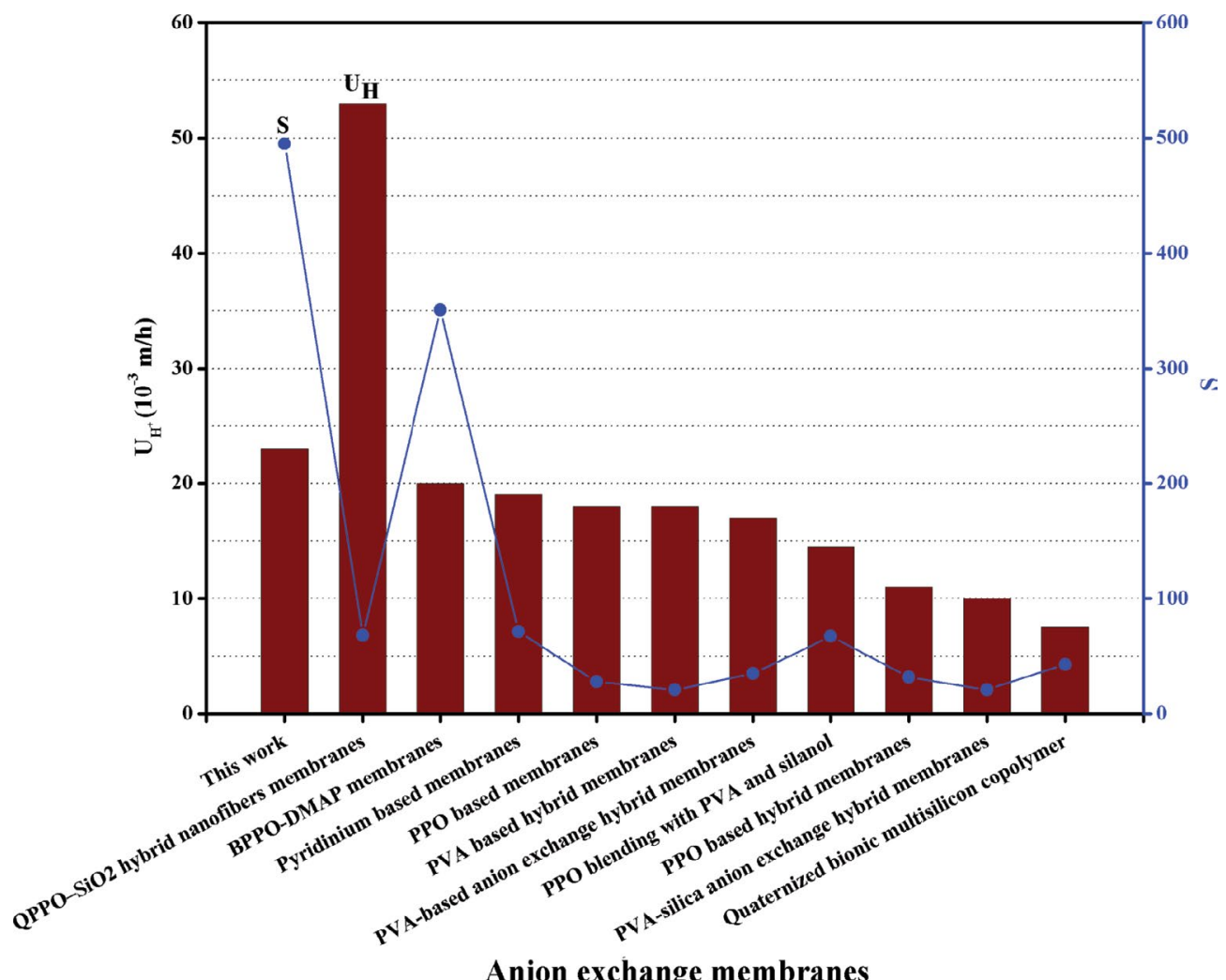

Fig. 7. (a) Comparison of membrane performances. Diffusion dialysis coefficients of acid $\mathrm{U}_{\mathrm{H}}^{+}$and separation factor $\mathrm{S}$ of our membranes ('this work') vs. reported membranes employing $\mathrm{HCl} / \mathrm{FeCl}_{2}$ as the model acidic waste solution.

prepared with $56 \%$ triethanolamine. Results show that weight loss takes place in three successive steps, corresponding to evaporation of adsorbed water at $80^{\circ} \mathrm{C}-130^{\circ} \mathrm{C}$, thermal deamination, and thermal oxidation of the polymer backbone. The second step at $230^{\circ} \mathrm{C}-240^{\circ} \mathrm{C}$ is explained by the degradation of quaternary ammonium groups [10].
The last step around $415^{\circ} \mathrm{C}$ is due to the degradation of the polymer backbone. Overall, our membranes have excellent thermal stability below $300^{\circ} \mathrm{C}$.

The chemical stability of the membrane was also tested by immersion into $\mathrm{HCl} / \mathrm{FeCl}_{2}$ for 2 weeks at $55^{\circ} \mathrm{C}$ (Fig. $8 \mathrm{~b}$ ). Results show a weight loss of about $15 \%$, in agreement
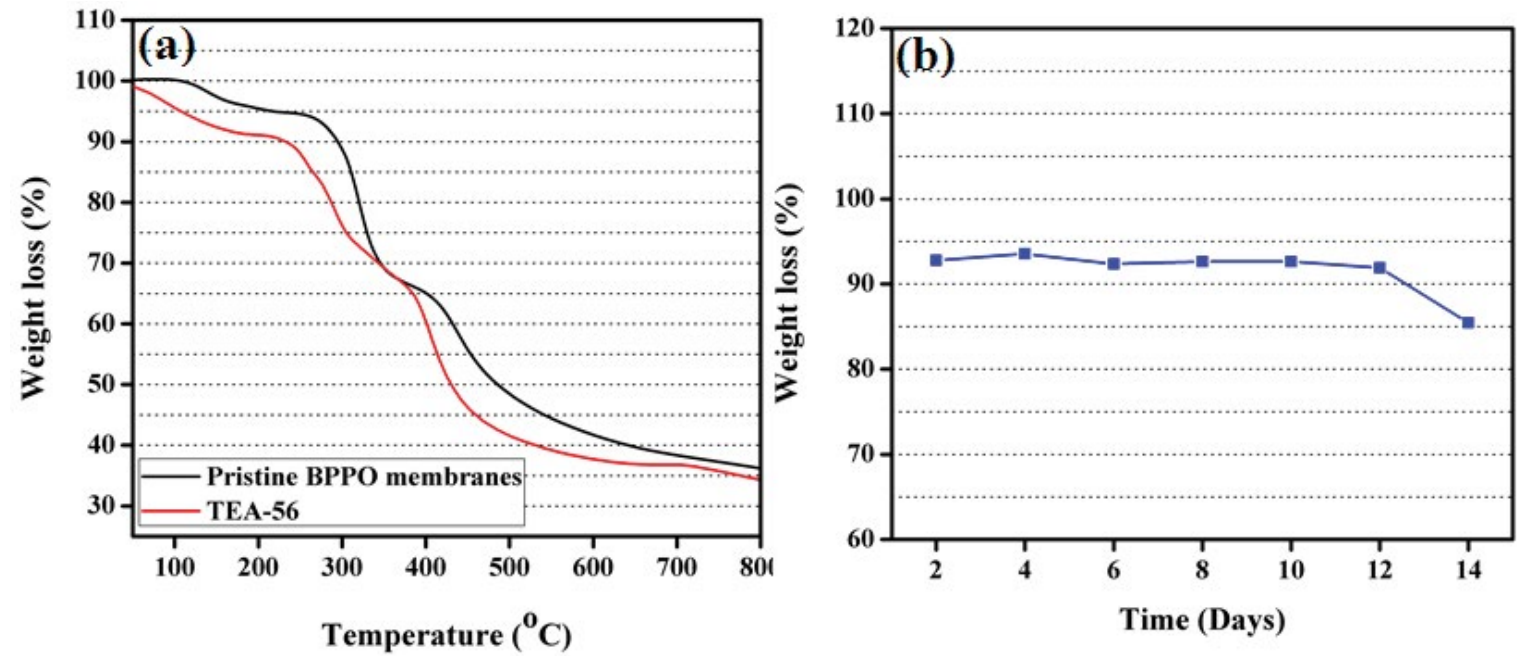

Fig. 8. (a) Thermogravimetric analysis of the pristine membrane and the membrane prepared with 56\% triethanolamine (TEA-56) and (b) Weight loss of the TEA-56 membrane after immersion in $\mathrm{HCl} / \mathrm{FeCl}_{2}$ feed solution for two weeks at $55^{\circ} \mathrm{C}$, showing high chemical stability. 
Table 2

Tensile strength (TS) and elongation at break of the prepared anion exchange membranes

\begin{tabular}{lllll}
\hline Membranes & TEA-19 & TEA-31 & TEA-44 & TEA-56 \\
\hline TS (MPa) & 31.85 & 31.38 & 23.51 & 19.27 \\
$E_{b}(\%)$ & 12.53 & 18.0 & 38.88 & 39.47 \\
\hline
\end{tabular}

with our previous reported membranes [10]. Moreover, we also observed that the color of our membrane is unchanged after two weeks of immersion in $\mathrm{HCl} / \mathrm{FeCl}_{2}$ feed solution at $55^{\circ} \mathrm{C}$. Overall, our AEMs display good chemical stability and are thus promising for acid recovery from wastewater.

\subsection{Mechanical stability}

We studied membrane mechanical stability by measuring tensile strength (TS) and elongation at break $\left(E_{b}\right)$ of AEMs prepared with $19 \%-56 \%$ triethanolamine, in the wet state (Table 2). Results show that TS ranges from 19.27 to $31.85 \mathrm{MPa}$. These values are higher than our previously reported AEM [58], which implies that the membranes of this work have excellent mechanical stability. The elongation at break ranges from $12.53 \%$ to $39.47 \%$, which are lower than hybrid AEMs [12]. TS decreases and elongation at break increases with triethanolamine content. The decrease in TS with enhanced IEC agrees with previous research [21]. The membrane prepared with $56 \%$ triethanolamine displays excellent flexibility due to lower tensile strength and higher elongation at break. By contrast, the AEM prepared with $19 \%$ triethanolamine exhibits high tensile strength and low elongation at break.

\section{Conclusion}

We prepared AEMs from PPO and triethanolamine by solution casting method. The successful synthesis was confirmed by FTIR spectroscopy. The homogeneous morphology was confirmed by SEM and AFM. Membranes exhibited optimal IEC and water uptake essential for diffusion dialysis applications. Membranes showed IEC of 1.28 to $2.29 \mathrm{mmol} / \mathrm{g}$, water uptake of $12 \%-117 \%$, LSR of $3.52 \%$ to $32.70 \%$. The IEC, water uptake, and LSR increase with triethanolamine content into the polymer matrix. The membranes were tested for acid recovery by diffusion dialysis. Results showed that membranes exhibit high value of $\mathrm{U}_{\mathrm{H}^{+}}^{+}$ of $1.3-23 \times 10^{-3} \mathrm{~m} / \mathrm{h}$, and of separation factor, from 37 to 495 , at room temperature. Membranes exhibit higher chemical, thermal, and mechanical stability. Overall, our findings reveal that the triethanolamine-functionalized AEMs are promising candidates for acid recovery from industrial acidic wastewater by diffusion dialysis.

\section{Acknowledgment}

The authors are highly thankful for the financial support from the Basic Science Center Program for Ordered
Energy Conversion of the National Natural Science Foundation of China (51888103).

\section{References}

[1] A. Agrawal, K.K. Sahu, An overview of the recovery of acid from spent acidic solutions from steel and electroplating industries, J. Hazard. Mater., 171 (2009) 61-75.

[2] H.-F. Xiao, Q. Chen, H. Cheng, X.-M. Li, W.-M. Qin, B.-S. Chen, D. Xiao, W.-M. Zhang, Selective removal of halides from spent zinc sulfate electrolyte by diffusion dialysis, J. Membr. Sci., 537 (2017) 111-118.

[3] C. Cheng, Z. Yang, J. Pan, B. Tong, T. Xu, Facile and cost effective PVA based hybrid membrane fabrication for acid recovery, Sep. Purif. Technol., 136 (2014) 250-257.

[4] L. Zhu, X.D. Yu, M.A. Hickner, Exploring backbone-cation alkyl spacers for multi-cation side chain anion exchange membranes, J. Power Sources, 375 (2018) 433-441.

[5] M.I. Khan, M. Khraisheh, F. Almomani, Fabrication and characterization of pyridinium functionalized anion exchange membranes for acid recovery, Sci. Total Environ., 686 (2019) 90-96.

[6] J. Feng, J.C. Chen, B.W. Wei, S.J. Liao, Y.G. Yu, X.H. Li, Seriesconnected hexacations cross-linked anion exchange membranes for diffusion dialysis in acid recovery, J. Membr. Sci., 570-571 (2019) 120-129.

[7] M.I. Khan, R. Luque, P. Prinsen, A. Ur Rehman, S. Anjum, M. Nawaz, A. Shaheen, S. Zafar, M. Mustaqeem, BPPO-based anion exchange membranes for acid recovery via diffusion dialysis, Materials, 10 (2017) 266.

[8] A.N. Mondal, C.L. Cheng, M.I. Khan, M. Hossain, K. Emmanuel, L. Ge, B. Wu, Y.B. He, J. Ran, X.L. Ge, N. Ul Afsar, L. Wu, T.W. Xu, Improved acid recovery performance by novel Poly(DMAEMco- $\gamma$-MPS) anion exchange membrane via diffusion dialysis, J. Membr. Sci., 525 (2017) 163-174.

[9] M.I. Khan, A.N. Mondal, C.L. Cheng, J.F. Pan, K. Emmanuel, L. Wu, T.W. Xu, Porous BPPO-based membranes modified by aromatic amine for acid recovery, Sep. Purif. Technol., 157 (2016) 27-34.

[10] M.I. Khan, A.N. Mondal, K. Emmanuel, M. Hossain, N. Ul Afsar, L. $\mathrm{Wu}$, T.W. Xu, Preparation of pyrrolidinium-based anion-exchange membranes for acid recovery via diffusion dialysis, Sep. Sci. Technol., 51 (2016) 1881-1890.

[11] A.N. Mondal, C.H. Dai, J.F. Pan, C.L. Zheng, M. Hossain, M.I. Khan, L. Wu, T.W. Xu, Novel pendant benzene disulfonic acid blended SPPO membranes for alkali recovery: fabrication and properties, ACS Appl. Mater. Interfaces, 7 (2015) 15944-15954.

[12] A.N. Mondal, C.L. Cheng, Z. Yao, J.F. Pan, M. Hossain, M.I. Khan, Z.J. Yang, L. Wu, T.W. Xu, Novel quaternized aromatic amine based hybrid PVA membranes for acid recovery, J. Membr. Sci., 490 (2015) 29-37.

[13] K. Emmanuel, C.L. Cheng, B. Erigene, A.N. Mondal, M. Hossain, M.I. Khan, N. Ul Afsar, G. Liang, L. Wu, T.W. Xu, Imidazolium functionalized anion exchange membrane blended with PVA for acid recovery via diffusion dialysis process, J. Membr. Sci., 497 (2016) 209-215.

[14] X.C. Lin, E. Shamsaei, B. Kong, J.Z. Liu, D.Y. Zhao, T.W. Xu, Z.L. Xie, C.D. Easton, H.T. Wang, Asymmetrically porous anion exchange membranes with an ultrathin selective layer for rapid acid recovery, J. Membr. Sci., 510 (2016) 437-446.

[15] A.N. Mondal, C.L. Zheng, C.L. Cheng, M. Hossain, M.I. Khan, Z. Yao, L. Wu, T.W. Xu, Effect of novel polysiloxane functionalized poly(AMPS-co-CEA) membranes for base recovery from alkaline waste solutions via diffusion dialysis, RSC Adv., 5 (2015) 95256-95267.

[16] Y.B. He, J.F. Pan, L. Wu, L. Ge, T.W. Xu, Facile preparation of 1,8-diazabicyclo[5.4.0]undec-7-ene based high performance anion exchange membranes for diffusion dialysis applications, J. Membr. Sci., 491 (2015) 45-52.

[17] K. Emmanuel, C.L. Cheng, A.N. Mondal, B. Erigene, M. Hossain, N. Ul Afsar, M.I. Khan, L. Wu, T.W. Xu, Covalently cross-linked 
pyridinium based AEMs with aromatic pendant groups for acid recovery via diffusion dialysis, Sep. Purif. Technol., 164 (2016) 125-131.

[18] J. Ran, M. Hu, D.B. Yu, Y.B. He, M.A. Shehzad, L. Wu, T.W. Xu, Graphene oxide embedded "three-phase" membrane to beat "trade-off" in acid recovery, J. Membr. Sci., 520 (2016) 630-638.

[19] K. Emmanuel, B. Erigene, C.L. Cheng, A.N. Mondal, M. Hossain M.I. Khan, N. Ul Afsar, L. Ge, L. Wu, T.W. Xu, Facile synthesis of pyridinium functionalized anion exchange membranes for diffusion dialysis application, Sep. Purif. Technol., 167 (2016) 108-116.

[20] K. Emmanuel, C.L. Cheng, B. Erigene, A.N. Mondal, N. Ul Afsar, M.I. Khan, M. Hossain, C.X. Jiang, L. Ge, L. Wu, T.W. Xu, Novel synthetic route to prepare doubly quaternized anion exchange membranes for diffusion dialysis application, Sep. Purif. Technol., 189 (2017) 204-212.

[21] M.I. Khan, L. Wu, M.M. Hossain, J.F. Pan, J. Ran, A.N. Mondal, T.W. Xu, Preparation of diffusion dialysis membrane for acid recovery via a phase-inversion method, Membr. Water Treat., 6 (2015) 365-378

[22] E. Bakangura, C.L. Cheng, L. Wu, X.L. Ge, J. Ran, M.I. Khan, E. Kamana, N. Afsar, M. Irfan, A. Shehzad, T.W. Xu, Hierarchically structured porous anion exchange membranes containing zwetterionic pores for ion separation, J. Membr. Sci., 537 (2017) 32-41.

[23] X.C. Lin, S.J. Kim, D.M. Zhu, E. Shamsaei, T.W. Xu, X.Y. Fang, H.T. Wang, Preparation of porous diffusion dialysis membranes by functionalization of polysulfone for acid recovery, J. Membr. Sci., 524 (2017) 557-564.

[24] J.Y. Luo, C.M. Wu, T.W. Xu, Y.H. Wu, Diffusion dialysis-concept, principle and applications, J. Membr. Sci., 366 (2011) 1-16.

[25] D.-H. Kim, J.-H. Park, S.-J. Seo, J.-S. Park, S. Jung, Y.S. Kang, J.-H. Choi, M.-S. Kang, Development of thin anion-exchange pore-filled membranes for high diffusion dialysis performance, J. Membr. Sci., 447 (2013) 80-86.

[26] D.M. Stachera, R.F. Childs, A.M. Mika, J.M. Dickson, Acid recovery using diffusion dialysis with poly(4-vinylpyridine)filled microporous membranes, J. Membr. Sci., 148 (1998) 119-127.

[27] D.-H. Kim, H.-S. Park, S.-J. Seo, J.-S. Park, S.-H. Moon, Y.-W. Choi, Y.S. Jiong, D.H. Kim, M.-S. Kang, Facile surface modification of anion-exchange membranes for improvement of diffusion dialysis performance, J. Colloid Interface Sci., 416 (2014) 19-24.

[28] X. Yue, W.J. Wu, G.D. Chen, C.R. Yang, S.J. Liao, X.H. Li, Influence of 2,2',6,6'-tetramethyl biphenol-based anionexchange membranes on the diffusion dialysis of hydrochloride acid, J. Appl. Polym. Sci., 134 (2017) 45333.

[29] Z. Liu, X.B. Li, K.Z. Shen, P.J. Feng, Y.N. Zhang, X. Xu, W. Hu, Z.H. Jiang, B.J. Liu, M.D. Guiver, Naphthalene-based poly(arylene ether ketone) anion exchange membranes, J. Mater. Chem. A, 1 (2013) 6481-6488.

[30] W.J. Ma, C.J. Zhao, H.D. Lin, G. Zhang, H. Na, Poly(aryl ether ketone)s with bromomethyl groups: synthesis and quaternary amination, J. Appl. Polym. Sci., 120 (2011) 3477-3483.

[31] J. Pan, Y. Li, J.J. Han, G.W. Li, L.S. Tan, C. Chen, J.T. Lu, L. Zhuang, A strategy for disentangling the conductivitystability dilemma in alkaline polymer electrolytes, Energy Environ. Sci., 6 (2013) 2912-2915.

[32] X.H. Li, Y.F. Yu, Q.F. Liu, Y.Z. Meng, Synthesis and properties of anion conductive multiblock copolymers containing tetraphenyl methane moieties for fuel cell application, J. Membr. Sci., 436 (2013) 202-212.

[33] X.H. Li, Y.F. Yu, Q.F. Liu, Y.Z. Meng, Synthesis and properties of anion conductive ionomers containing tetraphenyl methane moieties, ACS Appl. Mater. Interfaces, 4 (2012) 3627-3635.

[34] D.Y. Chen, M.A. Hickner, Degradation of imidazolium- and quaternary ammonium-functionalized poly(fluorenyl ether ketone sulfone) anion exchange membranes, ACS Appl. Mater. Interfaces, 4 (2012) 5775-5781.

[35] C.M. Wu, Y.H. Wu, J.Y. Luo, T.W. Xu, Y.X. Fu, Anion exchange hybrid membranes from PVA and multi-alkoxy silicon copolymer tailored for diffusion dialysis process, J. Membr. Sci., 356 (2010) 96-104.
[36] X.C. Lin, J.R. Varcoe, S.D. Poynton, X.H. Liang, A.L. Ong, J. Ran, Y. Li, T.W. Xu, Alkaline polymer electrolytes containing pendant dimethylimidazolium groups for alkaline membrane fuel cells, J. Mater. Chem. A, 1 (2013) 7262-7269.

[37] N.T. Rebeck, Y.F. Li, D.M. Knauss, Poly(phenylene oxide) copolymer anion exchange membranes, J. Polym. Sci. Polym. Symp., 51 (2013) 1770-1778.

[38] G.G. Wang, Y.M. Weng, J. Zhao, D. Chu, D. Xie, R.R. Chen, Developing a novel alkaline anion exchange membrane derived from poly(ether-imide) for improved ionic conductivity, Polym. Adv. Technol., 21 (2010) 554-560.

[39] N.W. Li, M.D. Guiver, Ion transport by nanochannels in ioncontaining aromatic copolymers, Macromolecules, 47 (2014) 2175-2198.

[40] Q. Zhang, S.H. Li, S.B. Zhang, A novel guanidinium grafted poly (aryl ether sulfone) for high-performance hydroxide exchange membranes, Chem. Commun., 46 (2010) 7495-7497.

[41] J.H. Wang, S.H. Li, S.B. Zhang, Novel hydroxide-conducting polyelectrolyte composed of an poly(arylene ether sulfone) containing pendant quaternary guanidinium groups for alkaline fuel cell applications, Macromolecules, 43 (2010) 3890-3896.

[42] L. Liu, Q. Li, J.W. Dai, H. Wang, B.K. Jin, R. Bai, A facile strategy for the synthesis of guanidinium-functionalized polymer as alkaline anion exchange membrane with improved alkaline stability, J. Membr. Sci., 453 (2014) 52-60.

[43] C. Qu, H.M. Zhang, F.X. Zhang, B. Liu, A high-performance anion exchange membrane based on bi-guanidinium bridged polysilsesquioxane for alkaline fuel cell application, J. Mater. Chem., 22 (2012) 8203-8207.

[44] B.Z. Zhang, S. Gu, J.H. Wang, Y. Liu, A.M. Herring, Y.S. Yan, Tertiary sulfonium as a cationic functional group for hydroxide exchange membranes, RSC Adv., 2 (2012) 12683-12685.

[45] S. Gu, R. Cai, T. Luo, Z.W. Chen, M.W. Sun, Y. Liu, G.H. He, Y.S. Yan, A soluble and highly conductive ionomer for highperformance hydroxide exchange membrane fuel cells, Angew. Chem. Int. Ed., 48 (2009) 6499-6502.

[46] S. Gu, R. Cai, Y.S. Yan, Self-crosslinking for dimensionally stable and solvent-resistant quaternary phosphonium based hydroxide exchange membranes, Chem. Commun., 47 (2011) 2856-2858.

[47] S. Gu, J. Skovgard, Y.S. Yan, Engineering the van der waals interaction in cross-linking-free hydroxide exchange membranes for low swelling and high conductivity, ChemSusChem, 5 (2012) 843-848.

[48] L.H. Jiang, X.C. Lin, J. Ran, C.R. Li, L. Wu, T.W. Xu, Synthesis and properties of quaternary phosphonium-based anion exchange membrane for fuel cells, Chin. J. Chem., 30 (2012) 2241-2246.

[49] K.J. Noonan, K.M. Hugar, H.A. Kostalik IV, E.B. Lobkovsky, H.D. Abruña, G.W. Coates, Phosphonium-functionalized polyethylene: a new class of base-stable alkaline anion exchange membranes, J. Am. Chem. Soc., 134 (2012) 18161-18164.

[50] N. Ul Afsar, B. Erigene, M. Irfan, B. Wu, T.T. Xu, W.G. Ji, K. Emmanuel, L. Ge, T.W. Xu, High performance anion exchange membrane with proton transport pathways for diffusion dialysis, Sep. Purif. Technol., 193 (2018) 11-20.

[51] E. Bakangura, C.L. Cheng, L. Wu, Y.B. He, X.L. Ge, J. Ran, K. Emmanuel, T.W. Xu, Highly charged hierarchically structured porous anion exchange membranes with excellent performance, J. Membr. Sci., 515 (2016) 154-162.

[52] N.W. Li, T.Z. Yan, Z. Li, T. Thurn-Albrecht, W.H. Binder, Comb-shaped polymers to enhance hydroxide transport in anion exchange membranes, Energy Environ. Sci., 5 (2012) 7888-7892.

[53] M.I. Khan, A.N. Mondal, B. Tong, C.X. Jiang, K. Emmanuel, Z.J. Yang, L. Wu, T.W. Xu, Development of BPPO-based anion exchange membranes for electrodialysis desalination applications, Desalination, 391 (2016) 61-68.

[54] M.I. Khan, C.L. Zheng, A.N. Mondal, M. Hossain, B. Wu, K. Emmanuel, L. Wu, T.W. Xu, Preparation of anion exchange membranes from BPPO and dimethylethanolamine for electrodialysis, Desalination, 402 (2017) 10-18. 
[55] M.I. Khan, R. Luque, S. Akhtar, A. Shaheen, A. Mehmood, S. Idress, S.A. Buzdar, A. Ur Rehman, Design of anion exchange membranes and electrodialysis studies for water desalination, Materials, 9 (2016) 365.

[56] A. Kumar, V. Kumar, P.K. Sain, M. Kumar, K. Awasthi, Synthesis and characterization of polyaniline membranes with secondary amine additive containing $\mathrm{N}, \mathrm{N}^{\prime}$-dimethyl propylene urea for fuel cell application, Int. J. Hydrogen Energy, 43 (2018) 21715-21723.

[57] M.I. Khan, Comparison of different quaternary ammonium groups on desalination performance of BPPO-based anion exchange membranes, Desal. Water Treat., 108 (2018) 49-57.

[58] M.I. Khan, M. Khraisheh, Synthesis and characterization of stable anion exchange membranes for desalination applications, Desal. Water Treat., 113 (2018) 36-44.

[59] T.W. Xu, W.H. Yang, Fundamental studies of a new series of anion exchange membranes: membrane preparation and characterization, J. Membr. Sci., 190 (2001) 159-166.

[60] C.M. Wu, Y.H. Wu, M. Gong, T. Xu, New anion exchanger organic-inorganic hybrids and membranes from a copolymer of glycidylmethacrylate and -methacryloxypropyl trimethoxy silane, J. Appl. Polym. Sci., 102 (2006) 3580-3589.

[61] C.G. Arges, L.H. Wang, M.-s. Jung, V. Ramani, Mechanically stable poly(arylene ether) anion exchange membranes prepared from commercially available polymers for alkaline electrochemical devices, J. Electrochem. Soc., 162 (2015) F686-F693.

[62] Y. Li, T.W. Xu, M. Gong, Fundamental studies of a new series of anion exchange membranes: membranes prepared from bromomethylated poly(2,6-dimethyl-1,4-phenylene oxide) (BPPO) and pyridine, J. Membr. Sci., 279 (2006) 200-208.
[63] J.Y. Luo, C.M. Wu, Y.H. Wu, T.W. Xu, Diffusion dialysis of hydrochloride acid at different temperatures using $\mathrm{PPO}-\mathrm{SiO}_{2}$ hybrid anion exchange membranes, J. Membr. Sci., 347 (2010) 240-249.

[64] X.C. Lin, E. Shamsaei, B. Kong, J.Z. Liu, T.W. Xu, H.T. Wang, Fabrication of asymmetrical diffusion dialysis membranes for rapid acid recovery with high purity, J. Mater. Chem. A, 3 (2015) 24000-24007.

[65] Y.H. Wu, M.M. Jiang, J. Cao, T.W. Xu, F.L. Mao, Combination of $\mathrm{OH}^{-}$ions and -OH groups within QPPO/PVA hybrid membranes for acid recovery, Desal. Water Treat., 57 (2016) 21023-21033.

[66] Y.H. Wu, C.M. Wu, Y. Li, T.W. Xu, Y.X. Fu, PVA-silica anionexchange hybrid membranes prepared through a copolymer crosslinking agent, J. Membr. Sci., 350 (2010) 322-332.

[67] Y.H. Wu, J.Y. Luo, C.M. Wu, T.W. Xu, Y.X. Fu, Bionic multisilicon copolymers used as novel cross-linking agents for preparing anion exchange hybrid membranes, J. Phys. Chem. B, 115 (2011) 6474-6483.

[68] J.F. Pan, Y.B. He, L. Wu, C.X. Jiang, B. Wu, A.N. Mondal, C.L. Cheng, T.W. $\mathrm{Xu}$, Anion exchange membranes from hotpressed electrospun QPPO- $\mathrm{SiO}_{2}$ hybrid nanofibers for acid recovery, J. Membr. Sci., 480 (2015) 115-121. 